\title{
Benign Notochordal Cell Tumor
}

National Cancer Institute

\section{Source}

National Cancer Institute. Benign Notochordal Cell Tumor. NCI Thesaurus. Code

C121901.

An intraosseous benign tumor of notochord orig in that arises in the bones of the base of the skull, vertebral bodies, sacrum or coccyx. It contains vacuolated tumor cells without atypia, but lacks myxoid matrix, necrosis, and lobular architecture, which are features that characterize its malignant counterpart, chordoma. Most lesions are incidental findings. 